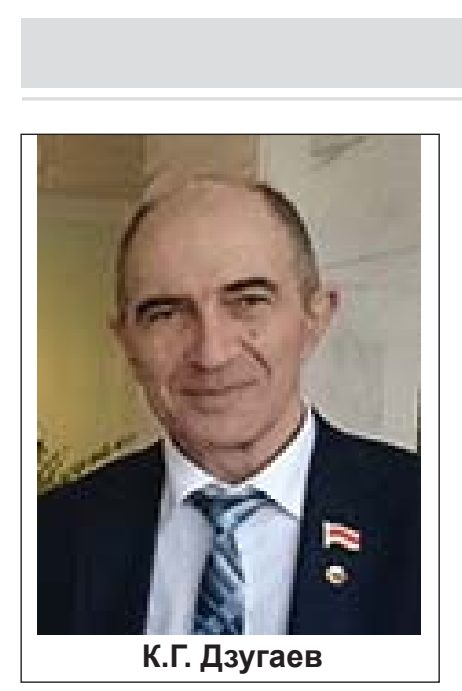

ВОПРОСЫ ПОЛИТОЛОГИИ

\section{DOI 10.23671/NNC.2018.1.12022}

\section{ЮЖНАЯ ОСЕТИЯ И БОЛЬШОЙ ТЕРРОР В СОВЕТСКОЙ ГРУЗИИ (2-я ЧАСТЬ) ${ }^{1}$ \\ К.Г. Дзугаев*}

\begin{abstract}
Аннотация. В статье рассматривается специфика репрессий 1937-1938 ге. в Южной Осетии, проводится количественный и качественный анализ имеющихся данных, делается вывод об использовании периода Большого террора грузинскими властями для подавления югоосетинского национально-освободительного движения.
\end{abstract}

Ключевые слова: репрессии, Грузия, Южная Осетия, 1937 год.

Осетины с древности имели сложное взаимодействие с грузинами, которое знало и блистательное союзничество, как это было во времена Сослана-Давида и Тамар [10], и тяжелую вражду - например, период «особа» $[4,5,6]$. В состав Российской Империи Осетия вошла в 1774 году, на четверть века раньше Картли-Кахетии; однако с приходом Российской империи грузинские фреодалы-тавады, находя поддержку у имперской власти, более полувека пытались закабалить осетин [14], пока наконец указом царя Николая I от 8 июня 1852 года осетины не были переведены в разряд казенных, т. е. государственных крестьян [1, с. 238]. Однако и после этого бывали неоднократные рецидивы этой политики подавления осетин.

Ко времени российской революции 1917 года осетины были довольно глубоко интегрированы в грузинское общество, занимали значительные земельные наделы (феномен хизанства) грузинских тавадов, сохраняя при этом личную свободу и имея договорные отношения с владельцами земли и все более урбанизируясь. Отношения между двумя национальными общинами развивались хотя и не без противоречий, но вполне успешно.

Ситуация резко изменилась с распадом Российской Империи и появлением Грузинской Демократической Республики под властью меньшевистского правительства Н. Жордания. Грузинский национализм, получивший наконец в Грузии государственную базу, немедленно приступил к построению этнократического государства и начал захватнические войны.
Для Южной Осетии это означало очередную попытку тбилисских властей взять под контроль родину южных осетин, проведя границу образовавшегося грузинского государства по Главному Кавказскому хребту. Южные осетины, в свою очередь, были категорически не согласны на грузинскую власть над собой, решительно настаивая на вхождение в состав России. Первые вооруженные столкновения произошли уже в 1918 году, затем еще более ожесточенные - в 1919 году; к 1920 году подавляющее большинство южных осетин были настроены пробольшевистски, а их лидеры старались поддерживать прямые контакты с Москвой, ясно выражая свое недоверие к грузинским большевикам.

Летом 1920 года большевистское восстание южных осетин, инспирированное из Москвы под воздействием (большей частью закулисным) грузинских высокопоставленных большевиков, получило первоначальный успех: повстанцы разгромили грузинские меньшевистские войска, заняли Цхинвал и объявили Советскую власть «от Они до Душети». Однако развить успех осетинскому командованию запретили и, более того, лишили военной поддержки². Грузинские власти, собрав практически все военные силы, имевшиеся в их распоряжении, бросили их на подавление «осетинской Вандеи» и после ряда сражений заняли Южную Осетию. Точнее говоря, уничтожили ее до состояния «чистого поля»: осетинские деревни сожжены ${ }^{3}[7]$, осетины частью перебиты (по разным данным, от пяти до пятнадцати тысяч человек), большинство (до 50000 человек) бежало через перевалы на Се-

“Дзугаев Коста Георгиевич - кандидат философских наук, доцент кафредры фрилософиии Юго-Осетинского госуниверситета им. А.А. Тибилова, старший научный сотрудник отдела новой и новейшей истории Юго-Осетинского НИИ им. З.В. Ванеева, е. Цхинвал, Республика Южная Осетия, заслуженный деятель науки РЮО, гендиректор Центра информационных технологий «Интеллектуальные ресурсы» (kostadzugaev@mail.ru).

${ }^{1}$ См. 1-ю часть в № 4, 2017.

2 Этому периоду посвящено специальное исследование в виде годовой научной работы 2014 г. в ЮОНИИ, где я работаю старшим научным сотрудником отдела новой и новейшей истории; по проведенному исследованию подготовлена и издана монографрия «Понятие «окна возможностей» применительно к интеграционно-воссоединительному процессу Осетии (1917-1921 г2.)»; в сокращенном виде освещение периода имеется и в нашей с В. Дзидзоевым монографиии «Южная Осетия в ретроспективе...».

${ }^{3}$ Один из главных палачей геноцида 1920 года В. Джугели успел до советизации Грузии издать книгу воспоминаний, где в числе прочего весьма красочно описывает уничтожение Южной Осетии. 
вер Осетии, немногих оставшихся осетин принялись расселять по самым малопригодным для жизни местностям Грузии, а саму Южную Oceтию, на тот момент уже как бы бывшую, стали заселять грузинскими горцами.

Несомненно, при сохранении независимого грузинского государства ни Южной Осетии, ни осетин как этноса в Грузии не стало бы. Но коммунистическая идея, владевшая умами большевистского руководства в Москве, имела атрибут расширения до максимально возможных пределов, и в 1921 году Грузия, как и все Закавказье, была присоединена к создававшемуся Союзу Советских Социалистических Республик. Южная Осетия была восстановлена, а осетины большей частью возвращены на свои пепелища. При этом, однако, грузинские большевики воспользовались ситуацией в своих этнополитических целях настолько, насколько смогли это сделать: Южная Осетия, вопреки неоднократно выраженному волеизъявлению народа, была введена в состав советизированной Грузии, для противостояния этому решению у большевистских лидеров южных осетин попросту не было политического ресурса; от Южной Осетии был административно-насильственно оторван КобиТрусовский регион (к настоящему времени полностью зачищенный от осетинского населения; выходцам из этой части Осетии теперешние грузинские власти ставят препятствия к посещениям своих сел); югоосетинская республика была аппаратными интригами понижена в статусе до автономной области, и т. п.

Московское руководство при этом поступало вполне логично, если исходить из целей государственного строительства. И. Сталин, будучи наркомом по делам национальностей (а с апреля 1922 года - Генеральным секретарем ЦК ВКП(б)), глубоко знал положение в Грузии и, отдавая себе отчет в ненадежности пребывания Грузии в составе СССР, рассматривал Абхазию и Южную Осетию в составе Грузии как своего рода «якоря», удерживающие грузинскую власть, а еще более грузинское общество от умонастроений о независимости. С другой стороны, этим объясняется и поистине удивительная мягкость, с которой новая, большевистская власть обращалась со своими, казалось бы, злейшими врагами; так, «для контакта и взаимного понимания с грузинской интеллигенцией делается все возможное. К бывшему меньшевистскому правительству по инициативе грузинской интеллигенции выехала делегация в лице членов Учредительного собрания - Натадзе, Кикодзе, Глонти и Михаила Церетели с предложением прекращения дальнейшей борьбы и признания Советской власти, причем
Советское правительство обещает полную амнистию всем членам бывшего правительства» [12, с. 172] (!). Но ведь эти люди пролили реки крови и грузин (большевиков-грузин они расстреливали сотнями), и других народностей Грузии? Тем не менее все меньшевики, оставшиеся в Грузии, пользовались прямо-таки тепличным режимом вплоть до попытки вооруженного мятежа в августе 1924 года: лишь после этого власть начала применять против них силу, весьма, впрочем, выборочно. И лишь в 1937-1938 годах грузинский меньшевизм получил мощный удар, в том числе и в отношении грузин, проживающих в ЮОАО (большинство дел содержит обвинения именно в меньшевизме).

Стремление югоосетинских лидеров и общества в целом к воссоединению Осетии не было устранено с политической повестки дня южных осетин, равным образом как и грузинский национализм был более чем присущ тбилисским коммунистам. Борьба, носившая столь ожесточенный характер в 1917-1920 годах, приняла теперь другие формы, но не стала менее напряженной. Осетинские коммунисты видели, что тбилисский центр не прекращает ассимиляционного давления на южных осетин, и хорошо понимали перспективы при сохранении сложившегося положения вещей.

Поэтому в 1925 году они решились на вторую попытку воссоединения, поддержанную на сей раз публично и достаточно энергично североосетинским руководством ${ }^{4}$. Этот порыв был остановлен грузинским руководством лишь весьма большими стараниями, после чего тбилисское высшее чиновничество резко усилило давление на группу югоосетинских лидеров, ведя против них разнообразную подрывную работу, прежде всего с целью разобщить их и посеять между ними недоверие. Надо признать, во многом это удалось.

В 1936 году югоосетинское руководство, к тому времени сильно ослабленное и эрозированное, видя надвигающуюся опасность полного национального поражения и этнического исчезновения в качестве южной ветви осетинского народа, воспользовалось всенародным обсуждением проекта новой «сталинской» Конституции СССР и решилось на последнюю для себя отчаянную попытку воссоединения с Северной Осетией. Но общеполитические условия к тому времени качественно изменились, и для югоосетинских активистов это стало катастрофой: практически все носители осетинской национальной активности были истреблены грузинским НКВД, получившим от центрального руководства достаточные для этого полномочия. Руководил этим процессом непосредственно Л. Берия ${ }^{4}$.

${ }^{4}$ Перипетиям этого периода также посвящено мое отдельное исследование - монографиия «Понятие «окна возможностей» применительно к интеграционно-воссоединительному процессу Осетии» (Цхинвал, 2017). 
Разумеется, грузинское государство, что при меньшевиках, что при большевиках, видело в осетинских активистах воссоединения и всех им сочувствующих своих злейших врагов. Государство по самой своей природе ничего не забывает и ничего не прощает, поэтому «окончательное решение» «осетинского вопроса» в годы Большого террора приняло столь неумолимые для южных осетин формы: процент расстрелянных среди репрессированных южных осетин составил, как указывалось, 44,44 \% (против 21,9 \% у грузин), а 10 лет лагерей получили еще 40,74 \%.

В своей с В. Дзидзоевым монографии и статье по этой теме мы привели показательный список репрессированных осетин из 119 человек [9, с. 118-125], вся вина этих людей состояла в том, что они хотели единства Осетии. Истребляли в первую очередь самых одаренных, высокообразованных южных осетин, при этом зачастую репрессия захватывала и семью, близкий круг родственников арестованного. «Никакими иными реальными причинами эту часть репрессий объяснить невозможно, так как биографии репрессированных являются лучшими доказательствами их преданности идеям коммунизма, социальной справедливости, активного социалистического строительства, личной порядочности и честности, общественного признания и уважения» [8, с. 28]. Но наиболее тщательно, повторяю, уничтожались осетины, ставившие вопрос воссоединения.

Так, В. Ванеев публикует фротографию участников президиума первого съезда писателей Северной и Южной (т. е. единой в данной конкретике) Осетии 1930 года: из девяти человек шестеро репрессированы, причем четверо погибли. Фотография оргкомитета первой олимпиады искусств Осетии: из девяти человек репрессировано семеро, большинство расстреляно [3, с. 9-10].

ПО ЦГА РЮО также дает этому выводу документальные подтверждения.

Так, в Определении № 1225/н Военного трибунала Закавказского военного округа от 22 июня 1956 г. при рассмотрении протеста прокурора на решение тройки при НКВД ГССР от 31 декабря 1937 г. в отношении Санакоева Владимира (Серо) Аржевановича указывалось, что «САНАКОЕВ был признан виновным в том, что он с 1920 года вел пропаганду за отторжение Юго-Осетии от Грузии (...)»[13, л. 12]. То есть то, что в 1920 году было предметом вооруженной борьбы с грузинскими меньшевиками, что в 1925 году принималось к рассмотрению И. Ста- линым как возможный вариант решения проблемы, и что даже еще в 1936 году воспринималось пусть как ошибочное и недопустимое, но все же партийно-коллегиальное предложение, теперь уже, в 1937 году, для грузинских властей стало уголовно наказуемым преступлением, и Москва в рамках новых «правил игры» молчаливо с этим согласилась.

Один из ярких и сильных лидеров югоосетинского национального движения Александр Михайлович Джатиев вызывал у тбилисских коммунистических бонз особую ненависть. Наблюдая изнутри тенденцию растущего давления на югоосетинское руководство и видя надвигающуюся беду, он попытался спастись, сумев организовать свой переезд в Северную Осетию. Спастись не удалось: он был арестован североосетинским НКВД, и ему инкриминировали все то же непрощаемое преступление: «Наши разговоры о необходимости объединения Южной и Северной Осетии привели к тому, что явилась действительная необходимость работы по пропаганде осетинских буржуазно-националистических идей. Он заявил, что без такой работы он не представляет себе существование крепко спаянной нации. (...) Александр ДЖАТИЕВ на чрезвычайной партийной конференции в ноябре 1920 года, в городе Владикавказе выступил против Серго Орджоникидзе. Выступление его было поддержано всей осетинской делегацией конференции» ${ }^{5}[13$, л. 91]; «Примерно в 1925-26 г. г. ДЖАТИЕВ и его контргруппа начала вести работу и переговоры с бывшим секретарем обкома партии Северной Осетии ТАКОЕВЫМ Ceменом (Симоном. - К.Д.), бывш. меньшевиком, об объединении Южной и Северной Осетии, со схождением в Закфедерацию. При этом ДЖАТИЕВ имел в перспективе после объединения поставить вопрос о самостоятельном вхождении объединенной Осетии в РСФСР» 6 [13, л. 92]; «ДЖАТИЕВ Александр Михайлович... руководитель антипартийной группировки, известной под названием «джатиевщина». Убежденный националист и ярый сторонник объединения Северной и Южной Осетии» ${ }^{7}$ [13, с. 93]; «Еще в 1921-21 г.г. (опечатка в тексте, мне неизвестно, как ее исправить; видимо, 1921-1925 гг. - К.Д.) в Северной Осетии поднимался вопрос о необходимости объединения с Юго-Осетией. (...) В этом вопросе у нас был полный контакт с южно-осетинским руководством, которое возглавлялось тогда ДЖАТИЕВЫМ Александром ${ }^{8}[13$, с. 93]. После ареста А. Джатиев допрашивался шесть раз на

\footnotetext{
${ }^{5}$ Цитируются показания свидетеля Симона Такоева, бывшего руководителя Северо-Осетинской Автономной Советской Социалистической Республики (СОАССР).

${ }^{6}$ Из показаний В.P. Козаева на допросе в НКВД ГССР.

${ }^{7}$ Там же. Л. 93. Из допроса Н.3. Джиоева.

${ }^{8}$ Из допроса Н. М. Саламова.
} 
протяжении двух месяцев, но свою вину категорически отрицал; следующие два месяца не допрашивался, но, очевидно, к нему применили такие меры воздействия, что он «добровольно» дал показания на ряд своих товарищей по революционной борьбе, полностью признал свою вину, был осужден и умер в Воркутлаге НКВД 6 марта 1943 года. Л. Берия считал его своим личным врагом, так как А. Джатиев осмелился на одном из пленумов ЦК КП(б) Грузии обвинить его в меньшевизме. После расстрела Л. Берия дело А. Джатиева было пересмотрено, и он полностью реабилитирован.

В логике данного рассмотрения, в связи с появлением в поле зрения исследователя Северной Осетии, появляется необходимость соответствующих знаний о репрессивной политике в этой осетинской республике в составе РСФСР (ныне Республика Северная Осетия-Алания в составе России). Специальный анализ мною не проводился; в последние годы опубликованы отрывочные сведения, позволяющие составить приблизительное представление по крайней мере об отдельных аспектах репрессий в СОАССР. Например, в ходе Великой Отечественной войны, при наступлении фашистских войск на Кавказ, Л. Берия просит у И. Сталина разрешения привести в исполнение приговоры к ВМН для заключенных в прифронтовых регионах; в СОАССР таковых оказалось на 15 ноября 1941 года 796 человек [16]. Для сравнения: в Грузинской ССР таковых - 395, в Краснодарском крае - 220 человек, в Ростовской области - 23 человека, в Кабардино-Балкарской АССР - 9 человек. Не позволяя себе поспешных выводов, тем не менее обязан отметить, что НКВД Северной Осетии возглавлял А.С. Заделава, членом Военного совета фрронта был А.Н. Саджая; оба - грузины [11, C. 9].

Теперь, с учетом вышеизложенного, как изощренное издевательство надо понимать обвинение в адрес Рутена Несторовича Гаглоева, инженера, инициатора и организатора строительства перевальной дороги между Севером и Югом Осетии - дороги, против строительства которой грузинское руководство боролось, как могло: «Обвиняется в шпионаже, вредительстве при постройке перевальной дороги» [13, л. 43]. Приговор, как нетрудно догадаться, - расстрел.

В этом же ракурсе понимается и обвинение Ермонии Захарьевны Чабиевой: «Поддерживала тесную связь с мужем Хубаевым В.3. до ареста и приносила пищу после ареста» [13, л. 69]. При- говор - 10 лет исправительно-трудовых лагерей (ИТЛ); муж - ВМН.

Об уровне соблюдения даже фрормальной законности можно судить, например, по специальному сообщению в Справке помощника прокурора ЮОАО Джинджихашвили по реабилитационному делу Тейбола (в другом написании - Тембол, что правильнее) Захарьевича Джиоева: «Характерным в данном деле является то, что решение бывш. тройки НКВД Груз. ССР о расстреле вынесено 15 августа 1937 года, а протокол об окончании следствия предъявлен 7 октября 1937 года, где учиняет подпись ДЖИОЕВ Т. Следовательно, решение о расстреле было вынесено до окончания следствия по делу, или же протокол об окончании дела был составлен после расстрела ДЖИОЕВА Т. 3. и учинена фиктивная подпись ${ }^{9}[13$, л. 29]. Или в другой Справке этого прокурора по делу Герсана Рожденовича Багаева (также расстрелян): «В деле имеется только самооговор БАГАЕВА о том, что он был завербован в к. р. (контрреволюционную. - К. Д.) организацию и показания ДЖИДЖОЕВА И. П., которое отпечатано на машинке и не подписано» [13, л. 32](!).

Вернемся, однако, ко второму списку. Из 216 репрессированных осетин 103 человека оказались коммунистами, что в процентах 47,69 \% (из 105 репрессированных грузин коммунистов 7 человек, 6,67 \%); комсомольцев 16 человек, 7,4\% (у грузин 6 человек, 5,71\%). Осетин с высшим образованием 52 человека, 24,07 \%, со средним образованием 87 человек, 40,28 \%. Работников партийно-советских органов (включая суды) 48 человек, 22,22 \%, служащих 83 человека, 38,43 $\%$; по этому поводу на первом листе архивного дела лаконично сообщается, что «были арестованы и расстреляны все секретари Юго-Осетинского обкома КП Грузии и районных комитетов партии, а также председатели Райисполкомов области» $[13$, л. 1]. Из служащих, что тоже важно для правильного представления о репрессивной политике, удар также пришелся большей частью по руководящему составу различных организаций и учреждений, т. е. в качественном отношении надо плюсовать эти две позиции, и получается 60,65 \% - практически все из югоосетинской элиты. Для более ясного понимания картины надо знать и то, что во второй половине 30-х годов XX века людей с высшим образованием в Южной Осетии было все еще очень мало. Если применить еще и авторские приемы для оценки степени интенсивности репрессий, т. е. принять

\footnotetext{
${ }_{9}^{9}$ В книге В. Ванеева «Люди, помните о нас» содержится описание эпизода, когда группа арестованных осетин, которых везли в крытом грузовике из Цхинвала в Тбилиси, после выезда из города была расстреляна двумя конвоирами, и на следующий день они составили справку о ликвидации арестованных якобы за попытку бегства, заставив подписать ее водителя грузовика. Эти двое убийц были осетинами, их имена В. Ванееву были известны, однако все его попытки найти документы об этом преступлении оказались безуспешны.
} 
во внимание то, что около 95 \% репрессированных - мужчины, а из них выделить возрастную группу от 20 до 60 лет, то мы получим те самые, такие же показатели, которые для абхазов авторы назвали катастрофой.

Думаю, что с учетом вышеизложенных политических фракторов и причин приводимые цифры в особых комментариях не нуждаются, свирепость расправы с осетинами ЮОАО в известном смысле, видимо, как минимум не уступает репрессиям в отношении абхазов: изъятия (как это называлось на профессиональном языке карательных органов) такого размера и качества представляли собой по сути «резекцию мозга» южной части осетинского народа, убиение в народе какой бы то ни было воли к сопротивлению. Приходится согласиться с выводом Ю. Цховребова: «Знакомясь с собранными документами репрессированных, диву даешься, как после такого смертельного удара нация смогла выстоять, как она поднялась на ноги и выжила» [16, с. 7].

Вывод авторов рассматриваемой главы хорошо согласуется с выявленными обстоятельствами карательной политики тбилисских властей в отношении южных осетин: «Репрессии в отношении обеих «полутитульных» наций, хотя и в весьма разной форме, использовались для того, чтобы «выхолостить» их автономию, переводя ее все более и более в символическую сферу, что способствовало гомогенизации Грузии под эгидой грузинской нации» [13, с. 262]. Однако здесь же следует указать на ошибочность дальнейших утверждений о том, что «противоречия между грузинами и осетинами были слабее, а тенденция к территориальному обособлению среди осетин только намечалась» [13, с. 263]: дело в том, что в случае с осетинами имело место не стремление к территориальному обособлению как таковому, а решительное намерение воссоединения с Севером Осетии в единое национально-государственное образование в составе России. Эта стратегия национального строительства жестко детерминировала движение осетинского этноса на Юге Осетии и в новейшее время - с 1989 года, предопределяя ирредентистскую сущность сецессии Южной Осетии из состава грузинского государства. Без понимания этого ключевого фрактора, на что не раз приходилось обращать внимание московских ученых и чиновников, просто невозможно выстраивание правильной политики на данном направлении. Добавлю также, что это хорошо понимают в Тбилиси, поэтому главная задача любой грузинской власти в отношении южных осетин в настоящее время - не допустить вхождения Республики Южная Осетия в состав России, выиграть время, дождаться складывания благоприятных общеполитических условий для восстановления кон- троля над «оккупированными» территориями; и в югоосетинском обществе нет ни малейших сомнений в том, что в этом случае произойдет. Память о терроре 1937-1938 гг. жива, а трагический опыт геноцидной агрессии в августе 2008 года убедил южных осетин (и не только их), что речь идет в конечном счете об уничтожении Южной Осетии как таковой, т. е. как этнотерриториальной родины осетин на южных склонах Главного Кавказского хребта.

Комментарии к остальным подглавам главы «Этнос и террор» кратки.

Так, с выводом по третьей «полутитульной» национальности - аджарцам - следует согласиться в целом: «С определенной осторожностью можно исходить из того, что репрессии ударили по аджарцам с большей силой, чем по грузинам» [13, с. 267], однако авторы справедливо указывают на необходимость значительно более углубленного (желательно поименного) анализа, так как вопрос с учетом аджарцев отличительно от грузин, действительно, методологически имеет в этом случае первостепенную важность.

Правильным представляется и вывод в отношении «советской», по обозначению авторов, национальности Грузии - армян: «Главной целью репрессий в отношении армян было нанесение удара по их укорененной позиции в грузинском обществе» [13, с. 275]. Аналогично и в отношении азербайджанцев («тюрок»): «Намерение властей, подвергших азербайджанцев сверхпропорциональным преследованиям, которые по своим масштабам и жестокости были сравнимы с репрессиями в отношении абхазов, могло в данном случае заключаться в том, чтобы воспрепятствовать артикуляции интересов данной этнической группы, будь это религиозные, культурные, социальные или политические интересы. Желательным побочным эфффектом репрессий было вытеснение «тюрок» с политической и общественной арены Грузии. Выиграть от всего этого могли, хотя и не по своей воле, этнические грузины» [13, с. 283].

Достаточно подробный и научно убедительный анализ проведен по репрессиям в отношении евреев - одной из национальностей, где процент расстрелянных резко превосходит аналогичный процент у осетин. При этом авторы верно указывают, что «речь шла, без всякого сомнения, о «чистке» партийных и государственных органов от евреев-ашкенази в духе формирования гомогенных политических и административных структур власти из представителей титульной нации. Эффрект «беспримерной карьеры» этих еврейских выдвиженцев в партии и государстве был нивелирован в результате «декоренизации» (Г. Симон), поскольку центр тяжести репрессий обрушился именно на эту группу (207 человек, 
2/3 или 72 \% от общего количества репрессированных евреев)» [13, с. 289]. Грузинские евреи, в отличие от ашкенази, репрессировались гораздо меньше - во-первых, потому, что признавались пригодными к включению в процесс гомогенизации Грузии, а во-вторых, потому, что имели гораздо более низкий социальный статус.

Из остальных национальностей Грузии, попавших под «каток» грузинского НКВД, показателен также вывод в отношении, например, греков: «Важнейшей причиной репрессий было то, что греки преимущественно селились на территории Абхазии, где в качестве группы, лишь условно поддающейся «включению», они препятствовали переходу территории автономной республики под власть Грузии. Тесная связь между территорией расселения и репрессиями была здесь особенно явной, поскольку греки, проживавшие вне Абхазии, подвергались репрессиям в гораздо меньшей степени» [13, с. 335]. Упоминаю об этом потому, что здесь же авторы делают правильную увязку с ситуацией с осетинами, несмотря на указанные выше методологические недостатки, повлекшие существенные искажения картины: «И все же в отношении осетин также проводилась политика национальной гомогенизации, как показывает специальное рассмотрение «качественных» параметров репрессий. Карательный аппарат целенаправленно истреблял малочисленную осетинскую элиту (служащих и членов ВКП(б)), тем самым цементируя низкий социальный статус этого этноса [13, с. 335]. Эту же цель преследовали, как следует из проведенного анализа, репрессии и в отношении евреев (ашкенази); авторы упоминают о латентном антисемитизме, однако у грузинского националэкстремизма антиеврейская установка всегда была столь же нескрываемой, как и антиосетинская.

В подглаве «Расизм или геноцид?» авторы делают важный обобщающий вывод: «Итак, в ходе массовых операций НКВД, бесспорно, имело место повышение значимости этнической компоненты, однако в СССР не произошло коренной смены парадигмы в направлении доминирования критерия этничности вплоть до его абсолютизации в форме биологизации террора, как это было в национал-социалистической Германии в случае с евреями, а также синти и рома. (...) В контексте массовых репрессий НКВД 1937-1938 гг. не может идти речи об этнических чистках, не говоря уже о геноциде» [13, с. 344]. Соглашаясь в целом с этим выводом, считаю необходимым сделать принципиальное пояснение. Карательную политику грузинского НКВД в отношении южных осетин действительно, если придерживаться строго научных критериев в конкретике данного рассмотрения, не следует признавать этниче- ской чисткой; готов согласиться даже и с тем, что затруднительно определять ее как геноцид. Однако, оставаясь в той же логике научного рассмотрения, мы обязаны анализировать террор 1937-1938 годов в отношении осетин не как изолированное явление, а как системный элемент политики центральных властей Грузии, направленной на подавление осетин с целью их полной ассимиляции в интересах гомогенизации грузинской нации и, соответственно, ликвидации Южной Осетии в целях унитаризации государственно-территориального устройства Грузии. При таком подходе - а он является методологически неуязвимым - трагедия 1920 года дефинируется как очевидный акт геноцида, террор 1937-1938 года - как одно из наиболее кровавых проявлений геноцидной политики в отношении осетин, искусственное сдерживание социально-экономического и демографического развития ЮОАО - как политика «мягкого» геноцида, а что касается грузинских агрессий против Южной Осетии новейшего времени, т. е. войн 1991-1992 годов, 2004 года, и особенно геноцидной агрессии в августе 2008 года, то не признавать это геноцидом для любого непредвзятого наблюдателя невозможно. Другое дело, что добиться политического и тем более юридического признания этого геноцида со стороны т. наз. «международного сообщества» в обозримом будущем представляется крайне маловероятным...

Авторы правы в том, что не считают депортации народов, проживавших в Грузии, следствием местной национальной политики: «Депортации проводились по прямому указанию из Москвы, по приказу партии, правительства и тайной полиции, а в годы войны - согласно постановлениям ГКО СССР, ответственность за их осуществление несло высшее руководство НКВД (...). То, что в результате выселения из Грузии «наказанных народов» в распоряжении титульной нации и других «лояльных» этносов оказалось дополнительное жизненное пространство, было только побочным, хотя и желанным эффректом, в результате чего депортированным этносам было отказано в возвращении домой как после их реабилитации в 1956 г., так и после получения Грузией независимости в 1991 г.» [13, с. 346]. Да, «целью Большого террора в Грузии, в отличие от депортаций, было не физическое изгнание целых этносов, а систематическое насильственное дисциплинирование и маргинализация наций (...) В Грузии Большой террор в значительной мере придал толчок процессу формирования грузинской нации и парадоксальным образом способствовал усилению грузинского национализма» [13, с. 346].

И далее подводится общий итог главы «Этнос и террор»: «Однако и для самой Грузии по- 
следствия политики ассимиляции в отношении национальных меньшинств, осуществлявшейся местными партийными и государственными элитами репрессивными методами, были драматическими. Именно в 1930-е гг., с опорой на старые традиции грузинского национализма образца XIX века, а возможно, и еще более раннего времени, были заложены основания не только для отделения абхазов и осетин, но и для «[...] этнокультурного определения грузинской нации», которое действует еще и сегодня, нанося урон единству и благосостоянию страны. В Грузии до сих пор царит представление о «Картвелоба», грузинском духе, согласно которому грузинское происхождение (этнические грузины, мингрелы, сваны, лазы) ценится выше, чем фракт принадлежности к грузинскому государству, чем грузинское граж-

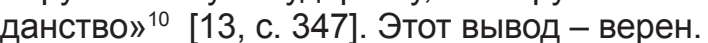

Следующая глава называется (весьма символично) «Грузия в пути» и представляет собой раздел «Дискуссия», который авторы, по зрелому размышлению, решили включить непосредственно в текст издания. На мой взгляд, это тоже верное решение, и, более того, по сути единственное; продиктовано оно тем, что и должно было случиться с представленным грузинской стороне текстом исследования: «В преддверии публикации книги «Большевистский порядок в Грузии. Большой террор в маленькой кавказской республике» весьма оживленную дискуссию вызвала глава «Этнос и террор» [13, с. 375]. За этой дипломатически обтекаемой формулировкой скрывается, как нетрудно догадаться, категорическое неприятие грузинским сообществом историков и смежных специалистов самой парадигмы проведенного авторитетным коллективом большого и очень значимого исследования. Тем не менее по итогам обсуждения все же было принято решение о публикации, и авторы выражают надежду, что возможность опубликовать такую книгу является «одним из показателей того, что страна находится на пути к становлению демократического и плюралистического государства, в котором история более не является средством защиты государственных и идеологических интересов» $[13$, с. 376]. Присоединяюсь с аналогичной надеждой к этому мнению.

Благодарю М. Юнге и его коллег за проявленную в ходе их исследования научную добросовестность и гражданскую позицию; отдельная благодарность г-ну М. Юнге за его предложение мне высказаться по указанным темам - для меня это также одно из доказательств стремления авторов к объективности.

\section{ЛИТЕРАТУРА}

1. Блиев М.М. Южная Осетия в коллизиях российско-грузинских отношений. - М., 2006. С. 238.

2. Большевистский порядок в Грузии. Издание в 2 томах. Составители Марк Юнге, Бернд Бонвеч. - М., 2015. 640 с. (Макет представлен в электронном виде)

3. Ванеев В.Д. Люди, помните о нас. - Цхинвал, 2005. 182 с. 4. Гаглойти Ю.С. Аланы и вопросы этногенеза осетин. Тбилиси, 1966.

5. Гаглойти Ю.С. Алано-Георгика. Сведения грузинских источников об Осетии и осетинах. - Владикавказ, 2007.

6. Гаглойти Ю.С. Избранные труды. Т. 1. / Составитель и научный редактор Дзугаев К.Г. - Цхинвал, 2010.

7. Джугели В. Тяжелый крестъ. Записки Народногвардейиа. - Тифрлисъ, 1920 (http://iarir.ru/node/61).

8. Дзидзоев В.Д., Дзугаев К.Г. 1937 год в Южной Осетии // Вестник Владикавказского научного центра. Том. 7. № 1. 2007. C. 23-30.

9. Дзидзоев В.Д., Дзугаев К.Г. Южная Осетия в ретроспективе грузино-осетинских отношений. - Цхинвал, 2007. $271 \mathrm{c}$.
10. Дзидзоев В.Д., Дзугаев К.Г. Сослан-Давид Царазон в истории Грузии и Осетии: фракты и гипотезы // Дарьял, № 2. Владикавказ, 2007. С. 159-175 (в соавторстве с В.Д. Дзидзоевым); в эл. доступе http://iarir.ru/node/97.

11. Книга Памяти. Т. 3. - Владикавказ, 1995.

12. Орджоникидзе Г.К. Статьи и речи. Т. 1. 1910-1926 г2. - М., 1956

13. Политический отдел Центрального Государственного Архива Республики Южная Осетия. Ф. 1, оп. 2, кор. 18 ว. 205.

14. Хронология исторических событий // История ЮгоОсетии в документах и материалах (1800-1864 ге. Составитель И.Н. Цховребов. Т. 2. Сталинир (ныне Цхинвал), 1960. С. 646-647).

15. Цховребов Ю.В. Южная Осетия и трагический 1937 год // Ванеев В. Д. Люди... С. 7 (предисловие к книге).

16. ... Чтобы не достались врагу // Социал-демократ Осеmuи. 2002, август, № 11.

17. https://ru.wikipedia.org/wiki/Население_Южной_Ocemuи.

\footnotetext{
10 При завершении работы над данным текстом в СМИ появились сообщения об отставке Пааты Закареишвили с поста министра по делам реинтеграции и назначении на должность Кетеван Цихелашвили. В общественном мнении РЮО эта новость воспринята однозначно негативно. П. Закареишвили был известен как сторонник осторожной, последовательной политики смягчения напряженности в грузино-осетинских отношениях, с преимущественным использованием гуманитарного инструментария; напротив, К Цихелашвили известна как убежденная националистка. Полномочный представитель Президента РЮО по постконфликтному урегулированию Мурат Джиоев, комментируя это назначение, отметил, что «Кетеван Цихелашвили не может даже произнести слово «Южная Осетия» и обзывает нас ругательным, оскорбительным термином «Самачабло» (обозначает «владения Мачабели»), который Гамсахурдиа и его сторонники извлекли в 1989 году из недр феодализма для большего оскорбления и унижения осетин (...). Говоря об участниках Женевских дискуссий, Цихелашвили даже не упоминает представителей Южной Осетии и Абхазии, которые на равных со всеми участниками представлены на дискуссиях. Она совершенно искажает в понимании читателя смысл и цель Женевских дискуссий, называя их переговорами в российско-грузинском аспекте. (...) Несколько лет грузинскую делегацию на Женевских дискуссиях возглавлял один из идеологов саакашизма и авторов плана "чистое поле», а сейчас одна из руководителей грузинской делегации откровенная звиадистка. И поспе этого многие удивляются, что нет явного прогресса на дискуссияху (http://aloninfo.ru/index.php/politika/item/475-ministr-po-delam-nenavisti-ketevan-tsikhelashvili).
} 


\title{
SOUTH OSSETIA AND THE GREAT TERROR IN SOVIET GEORGIA. Part 2.
}

\author{
K.G. Dzugaev
}

PhD, Associate Professor. SouthOssetian State University named after A.A.Tibilov

Abstrakt. The article deals with the specificity of the repression during 1937-1938 in South Ossetia, the quantitative and qualitative analysis of the available data is being carried out, the article concludes that the Georgian authorities had benefited during the period of the Great Terror to suppress the South Ossetian national movement.

Keywords: Repression, Georgia, South Ossetia, 1937 year.

\section{REFERENCES}

1. Bliev M.M. Yuzhnaya Osetiya v kolliziyakh rossiysko-gruzinskikh otnosheniy. - M., 2006. S. 238.

2. Bol'shevistskiy poryadok v Gruzii. Izdanie v 2 tomakh. Sostaviteli Mark Yunge, Bernd Bonvech. - M., 2015. 640 s. (Maket predstavlen $v$ elektronnom vide)

3. Vaneev V.D. Lyudi, pomnite o nas. - Tskhinval, 2005. $182 \mathrm{~s}$.

4. Gagloyti Yu.S. Alany i voprosy etnogeneza osetin. - Tbilisi, 1966.

5. Gagloyti Yu.S. Alano-Georgika. Svedeniya gruzinskikh istochnikov ob Osetii i osetinakh. - Vladikavkaz, 2007.

6. Gagloyti Yu.S. Izbrannye trudy. T. 1. / Sostavitel' i nauchnyy redaktor Dzugaev K. G. - Tskhinval, 2010.

7. Dzhugeli V. Tyazhelyy krest”. Zapiski Narodnogvardeytsa. - Tiflis", 1920 (http://iarir.ru/node/61).

8. Dzidzoev V.D., Dzugaev K.G. 1937 god v Yuzhnoy Osetii // Vestnik Vladikavkazskogo nauchnogo tsentra. Tom. 7. № 1. 2007. S. 23-30.

9. Dzidzoev V.D., Dzugaev K.G. Yuzhnaya Osetiya v retrospektive gruzino-osetinskikh otnosheniy - Tskhinval, 2007. $271 \mathrm{~s}$.

10. Dzidzoev V.D., Dzugaev K.G. Soslan-David Tsarazon v istorii Gruzii i Osetii: fakty i gipotezy // Dar'yal, № 2. Vladikavkaz, 2007. S. 159-175 (v soavtorstve s V.D. Dzidzoevym); v el. dostupe http://iarir.ru/node/97.

11. Kniga Pamyati. T. 3. - Vladikavkaz, 1995.

12. Ordzhonikidze G.K. Stat'i i rechi. T. 1. 1910-1926 gg. - M., 1956.

13. Politicheskiy otdel Tsentral'nogo Gosudarstvennogo Arkhiva Respubliki Yuzhnaya Osetiya. F. 1, op. 2, kor. 18, d. 205.

14. Khronologiya istoricheskikh sobytiy // Istoriya Yugo-Osetii v dokumentakh i materialakh (1800-1864 gg. Sostavitel' I.N. Tskhovrebov. T. 2. Stalinir (nyne Tskhinval), 1960. S. 646-647).

15. Tskhovrebov Yu.V. Yuzhnaya Osetiya i tragicheskiy 1937 god // Vaneev V. D. Lyudi... S. 7 (predislovie k knige).

16. ...Chtoby ne dostalis' vragu // Sotsial-demokrat Osetii. 2002, avgust, № 11

17. https://ru.wikipedia.org/wiki/Naselenie_Yuzhnoy_Osetii.

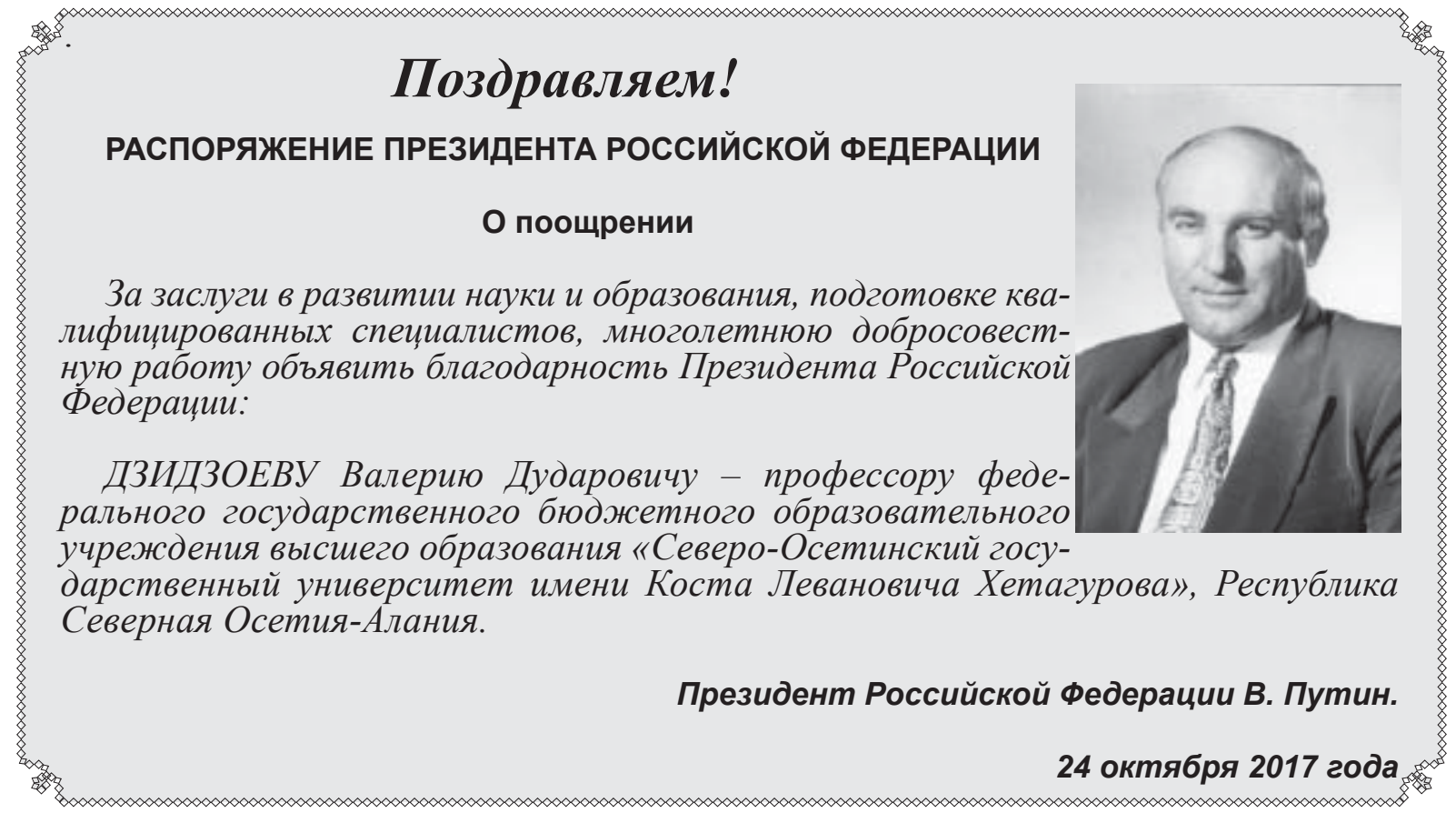

